\title{
Comentario a propósito de la prohibición de utilizar animales en sorteos o como reclamo publicitario en las leyes de protección animal ${ }^{1}$.
}

\section{María González Lacabex ${ }^{2}$}

Recientemente recibimos en el despacho el encargo de interponer denuncia administrativa por presunta infracción de la normativa de protección animal contra un establecimiento hostelero que había celebrado el sorteo de tres cerdos vivos, de apenas un mes de edad. En este caso, tanto la Ley autonómica como la propia Ordenanza municipal sobre tenencia y protección de los animales prohibía expresamente: "Ia donación de animales como reclamo publicitario, premio o recompensa, a excepción de negocios jurídicos derivados de la transacción onerosa de aquéllos" ${ }^{3}$. Una prohibición que en la actualidad, excepto en Asturias y Cantabria, se recoge en todas las legislaciones autonómicas de protección de los animales. Así, estas leyes disponen, con similar o idéntica redacción, que está prohibido donar animales como premio, reclamo publicitario, recompensa, gratificación o regalo de compensación, salvo en negocios jurídicos derivados de la transacción onerosa de animales.

Por lo general, cuando se denuncia un caso de abandono y/o maltrato animal (la agresión a un perro, la tenencia de un caballo en condiciones insalubres...) la reacción social y ciudadana que recibimos los agentes implicados suele ser de apoyo a dicha denuncia, pidiendo una firme aplicación del régimen sancionador previsto para estos

\footnotetext{
1 Vid. González Lacabex, María: Prohibido rifar animales (o de cómo avanzamos hacia la “descosificación” legal de los animales no humanos). www.animalexabogados.com. Febrero 2014.

${ }^{2}$ Abogada. Máster en Derecho del Medio Ambiente. Especialista Universitaria en Desarrollo Sostenible y Agenda 21 Local. Postgrado Animales, Derecho y Sociedad (UAB, 2011). Fundadora de ANIMALEX, despacho dedicado exclusivamente a Derecho Animal.

3 Ley 6/1993, de 29 de octubre, de Protección de los Animales en el País Vasco (artículo 5.d) y Ordenanza reguladora de la tenencia y protección de animales en el término municipal de Bilbao, de 29 de noviembre de 2000 (artículo 12.1.II).
} 
supuestos, e incluso lamentando la "tibieza" de las sanciones previstas. Sin embargo, en el caso que nos ocupa, algunas de las manifestaciones trasladadas a quien suscribe merecen su reflexión: "Sancionar esto... ¿no es un poco exagerado?" "¿Qué diferencia hay entre sortearlos o venderlos? Al final, en cualquiera de los casos los van a matar para comerlos." "¿No es una contradicción que por un lado se prohíba sortear animales y por otro se permita, por ejemplo, utilizarlos en espectáculos en los que sufren, como en los circos o las corridas de toros?"

Para dar respuesta a estas cuestiones y entender las contradicciones que, efectivamente, existen en nuestra actual normativa de protección animal es preciso atender al origen y la evolución de dicha legislación:

Las actuales leyes de protección animal básicamente tienen su origen en normas cuyo fin era proteger intereses exclusivamente humanos, principalmente económicos y de seguridad y salud públicas (como la protección del ganado frente a enfermedades o el control de la rabia). Poco a poco esas normas fueron evolucionando de la mano de una cada vez mayor sensibilidad social respecto a los intereses de los animales, en calidad de seres con capacidad de sentir. Un reconocimiento proclamado por la propia Unión Europea en su Tratado de Lisboa y que va siendo incorporado, incluso a nivel constitucional, por los ordenamientos jurídicos de otros países de nuestro entorno. En el caso más cercano encontramos a Cataluña, que en su propio Código Civil declara que "los animales no se consideran cosas" y que "sólo se les aplican las reglas de los bienes en lo que permite su naturaleza” ${ }^{\prime 4}$. Las mismas leyes autonómicas de protección animal recogen de una u otra manera reconocimientos en esa línea, eso sí, en forma de meras declaraciones generales de principios. Como ejemplo encontramos, nuevamente, el texto catalán ${ }^{5}$, pero también otros como los de Navarra ${ }^{6}$ o Andalucía ${ }^{7}$.

\footnotetext{
${ }^{4}$ http://www.derechoanimal.info/bbdd/Documentos/604.doc

${ }^{5}$ Artículo 2.2 del Decreto legislativo 2/2008, de 15 de abril, por el que se aprueba el Texto refundido de la Ley de protección de los animales en Cataluña: "Los animales son seres vivos dotados de sensibilidad física y psí quica, así como de movimiento voluntario, y deben recibir el trato que, atendiendo básicamente a sus necesidades etológicas, procure su bienestar". http://www.derechoanimal.info/bbdd/Documentos/458.pdf
} 
Pues bien, en dicha evolución estas leyes autonómicas de protección animal se han encontrado con el reto de afrontar en la práctica los inevitables conflictos de intereses que mayores niveles de protección de los animales suponen con respecto a la utilización de éstos en beneficio humano. Qué duda cabe que el dilema se ha resuelto siempre atendiendo a este último interés. Así, estas normativas proclaman con carácter general la protección de los animales, para a continuación salvaguardar los intereses humanos que se considera pudieran verse afectados por dicha protección, por ejemplo a través de excepciones legales ("quedan excluidos de la aplicación de esta ley..."), o del siempre recurrente permiso administrativo ("se prohíbe esta práctica si no cuenta con autorización de la Administración competente").

De esta manera, en aquellos ámbitos de utilización de los animales al servicio de los humanos en los que todavía se considera que el interés humano prevalece en todo caso - a pesar incluso de que pueda existir un sufrimiento para el animal implicado -, nos encontraremos con una barrera en esa evolución hacia una mayor y más efectiva protección legal de los animales.

De igual manera, allá donde se considera que no existe tal conflicto de intereses, es precisamente donde se permite a esas legislaciones llegar más lejos. Y es por este motivo que la misma ley que consiente la explotación y venta de animales para su consumo, no encuentra mayor problema en prohibir que sean usados como reclamo de un sorteo. No parece que las leyes de protección animal tengan dificultades en avanzar hacia cotas más elevadas de dicha protección siempre y cuando la misma no suponga poner en entredicho intereses humanos que se consideren irrenunciables.

\footnotetext{
${ }^{6}$ Exposición de Motivos de la Ley foral de protección de los animales en Navarra: "La consideración de los animales como seres vivos capaces de sufrir y la superación de toda visión del hombre como dueño y señor absoluto de un ilimitado derecho a su disposición (...)”.

http://www.derechoanimal.info/bbdd/Documentos/419.pdf

${ }^{7}$ Exposición de Motivos de la Ley de protección de los animales en Andalucía: “(...) los estudios realizados sobre las capacidades sensoriales y cognoscitivas de los animales no han dejado duda sobre la posibilidad de que éstos puedan experimentar sentimientos como placer, miedo, estrés, ansiedad, dolor o felicidad". http://www.derechoanimal.info/bbdd/Documentos/255.pdf
} 
Sin embargo, la prohibición de sortear animales resulta especialmente llamativa. El hecho de que un animal sea utilizado como objeto de una rifa o como premio en un concurso no tiene por qué llevar aparejada necesariamente una situación de maltrato. El animal puede estar perfectamente atendido, con sus necesidades cubiertas y además ser mantenido en estricto cumplimiento de la normativa administrativa, con todos los controles y permisos al día. ¿Por qué la ley prohíbe entonces con carácter general donar animales de esta manera? ¿Qué es lo que está protegiendo?

El objetivo que subyace en esta disposición legal no puede ser otro que el de prohibir la instrumentalización del animal, en un claro reconocimiento de que el mismo no es una cosa. Rifar un animal, tratarlo como un premio o un trofeo, supone un acto de desconsideración pública y manifiesta de aquél como ser vivo con capacidad de sentir. Así, se admite que podemos comprarlos y venderlos, disponer de ellos para nuestro uso y consumo, pero algo hay implícito en el hecho de sortearlos que no deja de friccionar con su consideración como seres sintientes. $Y$, no habiendo encontrado interés humano/motivo superior suficiente que justifique dicha actuación, el legislador no encuentra mayor problema en prohibirla (eso sí, dejando a salvo la utilización de animales con fines publicitarios en el marco de la compraventa de los mismos).

Así, la prohibición de utilizar animales como reclamo publicitario, premio o $\underline{\text { recompensa constituye seguramente (junto con la prohibición de embargar animales }}$ contenida en la legislación catalana $\left.{ }^{8}\right)$ uno de los principales avances legislativos no sólo en la protección de los animales frente a la crueldad y el sufrimiento, sino en la reivindicación del hecho fundamental de que no son cosas y de que por lo tanto son merecedores de un estatuto jurídico distinto al de los meros bienes muebles. Con ella, la ley abre (¿sin querer?) un resquicio a la aplicación práctica de tan importante reconocimiento, el del animal como ser sintiente que no puede ser cosificado. En definitiva, el legislador se descubre en este precepto admitiendo que, a pesar de que

\footnotetext{
${ }^{8}$ Decreto Legislativo 2/2008, de 15 de abril, por el que se aprueba el Texto refundido de la Ley de protección de los animales de Cataluña: "Los animales de compañía no pueden ser objeto de embargo en ningún procedimiento judicial" (artículo 2.4).
} 


\section{dA derecho ANIMAL la web center de los animales con derecho}

justifiquemos su utilización en nuestro beneficio, en realidad los animales no deberían ser tratados como cosas.

"Queda prohibida la donación de animales como reclamo publicitario, premio o recompensa..." A la vista de lo anterior, no subestimemos la importancia de una disposición legal como ésta, y reclamemos su cumplimiento allá donde observemos que haya podido ser vulnerada. Porque con la denuncia de este tipo de actividades, estamos haciendo algo más que solicitar la sanción de una mera infracción administrativa. Estamos reivindicando para los animales el estatuto que merecen, en función de lo que realmente son. 